\title{
A GIANT NODAL FORM OF BASAL CELL CANCER A CLINICAL CASE
}

\author{
Elena Efanova ${ }^{\bowtie} \odot$, Yuri Rusak $\odot$, Ekaterina Vasilyeva $\odot$ \\ Institute of Medicine, Surgut State University, Surgut, Russia \\ $\triangle$ el.efanova2011@yandex.ru
}

ABSTRACT - A clinical case of a giant nodal form of basal cell - a skin tumor developing from atypical basal cells of the epidermis and follicular epithelium-is presented. The diagnosis was confirmed by dermatoscopy and finally verified on the basis of the results of histological examination.

KEYW ORDS - giant basal cell carcinoma, dermatoscopy, basal cell carcinoma, skin tumors.

\section{DESCRIPTION}

An 82-year-old woman from a former Post-Soviet country, has referred to a dermatologist for a medical examination. At the time of the examination the patient complaints of a large formation in the left eyelid, periodically bleeding, causing aesthetic inconvenience. The patient considers herself sick for 6 years, when the complaints first appeared. The patient did not seek medical assistance and practiced self-medication. She reported that she periodically lived in Moldova and was repeatedly subjected to active insolation, including episodes of sunburn. She rejected occupational hazards and exposure to ionizing radiation. Medical history excludes hereditary and skin cancer. The patient denies tuberculosis, viral hepatitis, sexually transmitted diseases. She denies injuries and surgeries in the past. Currently, the patient has not been observed by specialists and does not take drugs for concomitant diseases. The patient suffered acute cerebrovascular accident in 2010. She denies allergic reactions to drugs in the past.

\section{LOCAL STATUS.}

The pathological skin process is limited, localized on the skin of the face, in the area of the upper eyelid on the left with a partial transition to the area of the nose and brow. It is represented by a node $4.5 \times 7 \mathrm{~cm}$ in diameter, with uneven bumpy roller-shaped edges of pink-red color, having the form of "pearls" and an extensive ulcer defect in the center with a thin serosanguineous scales-crust on the surface, when removing which erosion is detected (fig. 1). Parotid, ear, submandibular lymph nodes are not palpated.

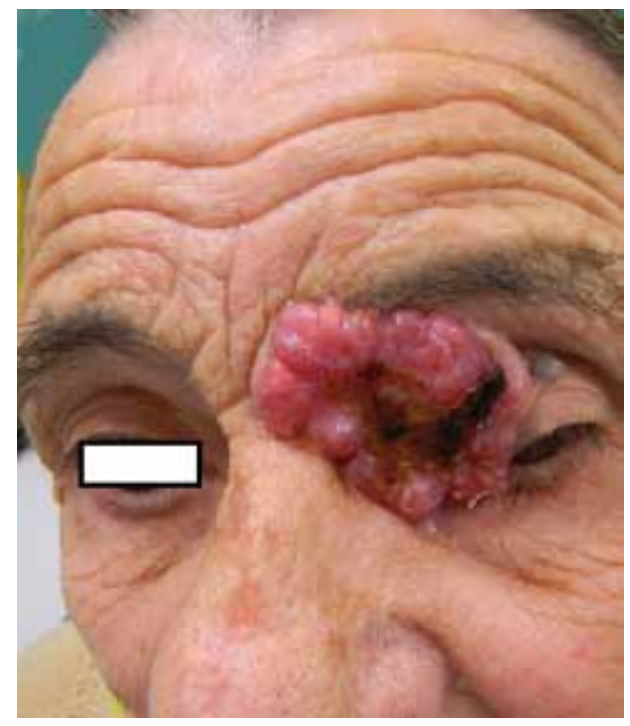

Fig. 1. Giant nodular basal cell carcinoma of the facial area

Dermatoscopy (by a trainee) revealed multiple atypical tree-like vessels (fig. 2, 3).

\section{RESULTS}

Total blood count: leukocytes $11,2 \cdot 10^{9} / 1$, erythrocytes $4,50 \cdot 10^{12} / 1$, platelets $298 \cdot 10^{9} / 1$, hemoglobin $130 \mathrm{~g} / \mathrm{l}, \mathrm{ESR} 25 \mathrm{~mm} / \mathrm{h}, \mathrm{N}$ 0\%, With 58\%, E7\%, M 7,9\%, L26,4\%, B0,7\%. Urinalysis: density 1030, protein - negative, red blood cells - negative, glucose negative, epithelium - single in the field of view, salt - negative, leukocytes $1-3$ in the field of view, ketone body - negative. Biochemical blood tests: ALT $64.8 \mathrm{u} / \mathrm{l}$, AST $37.4 \mathrm{u} / \mathrm{l}$, cholesterol $6.8 \mathrm{mmol} / \mathrm{l}$, urea $6.83 \mathrm{mmol} / \mathrm{l}$, total protein $74.3 \mathrm{~g} / \mathrm{l}$, alkaline phosphatase $247.56 \mathrm{u} / \mathrm{l}$, total bilirubin $74.3 \mathrm{mmol} / \mathrm{l}$, glucose $4.03 \mathrm{mmol} / \mathrm{l}$. Microreaction of precipitation is negative.

To determine treatment tactics the patient was sent to an oncologist. Histological results: presence of typical complexes of epithelial cells with dark nuclei, the absence of intercellular bridges, palisade-like complexes on the periphery. Connective tissue stroma in the form of beams. Between parenchyma and stroma a retention gap is visualized. Histological picture corresponds to basal cell carcinoma.

The further fate of the patient: at the readmission by the dermatologist, the patient refused treatment in 
Surgut and decided to undergo treatment in her home country.

Written informed consent was obtained from the patient for publication of this case report.

\section{CONCLUSION}

This clinical case is of interest to oncologists and dermatologists. Despite the fact that basal cell carcinomas are very common skin tumors, such gigantic sizes are rare and often represent neglected cases. Onco-
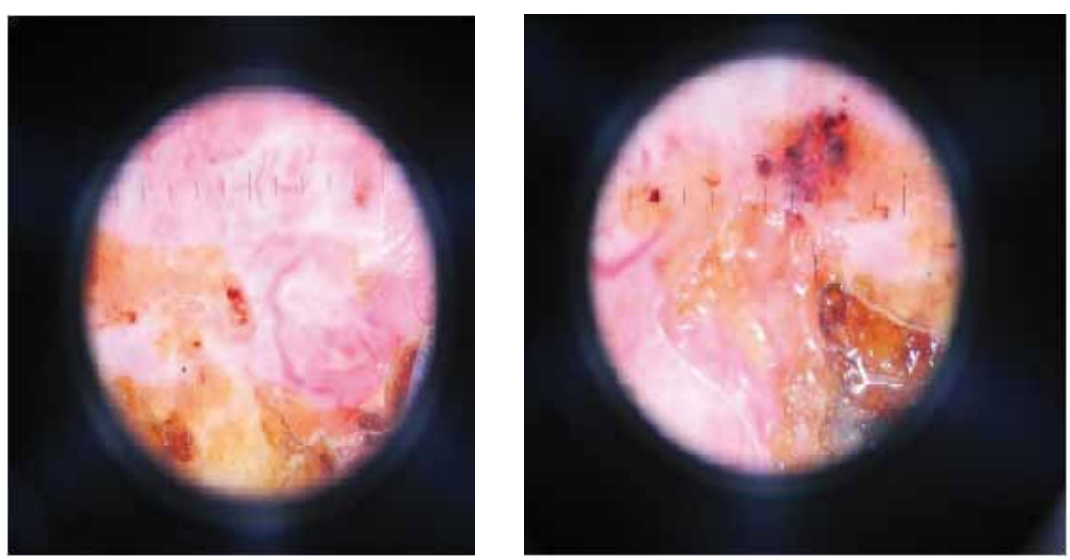

Fig. 2, 3. Dermatoscopic pattern of basal cell carcinoma. logical caution for the purpose of early detection of skin tumors is relevant not only among health professionals, but also among the population. 